\title{
SOSIALISASI NILAI-NILAI AGAMA PADA ANAK DALAM KELUARGA MUSLIM
}

\author{
Djazuli
}

\begin{abstract}
ABSTRAK
Agama pada umumnya memandang bahwa lembaga keluarga merupakan lembaga yang abadi dan suci. Lembaga tersebut dianggap sebagai bagian dari kodrat Illahi bagi setiap manusia baik laki-laki ataupun perempuan. Penempatan religi dalam perspektif sosiologis telah menempatkan religi pada kawasan yang sangat mendasar. Karena religi dalam pengertian agama merupakan prinsip dari segala prinsip dan azas dari segala azas
\end{abstract}

Kata Kunci: Sosialisasi, Nilai Agama, Keluarga Muslim

\section{A. Pendahuluan}

Agama dan kehidupan keluarga selalu menjadi perhatian manusia. Agama dan keluarga semakin luas dibicarakan, salah satu sebab karena agama dan keluarga saling mengukuhkan.

Agama selalu memberikan dukungan kepada keluarga, sehingga nampak keluarga dikuasai dengan nilai-nilai agama. Sebaliknya keluarga membutuhkan pengukuhan dan pelestarian keluarga akhimya akan menjadi pilar yang kuat dan terpercaya dalam pelestarian dan kuatnya agama.

Instansi yang paling sering dihadapkan dengan pertanyaan menyangkut masalah keluarga adalah agama. Karena agama bagaimanapun merupakan sumber moral di mana tatanankeluarga dibangun. Membangun keluarga berarti mengembalikan keyakinan hidup.

Agama pada umumnya memandang bahwa lembaga keluarga merupakan lembaga yang abadi dan suci. Lembaga tersebut dianggap sebagai bagian dari kodrat Illahi bagi setiap manusia baik laki-laki ataupun perempuan. Penempatan religi dalam perspektif sosiologis telah menempatkan religi pada kawasan yang sangat mendasar. Karena religi dalam pengertian agama merupakan prinsip dari segala prinsip dan azas dari segala azas. 
Agama dan keluarga selalu menjaga kestabilan hidupnya. Perubahan wawasan mengenai keluarga dan agama dan pengaruh yang terjadi dalam masyarakat dewasa ini sungguh mempersoalkan keluarga sampai keakarakamya dan persoalannya adalah bahwa justru keluarga dalam bentuknya sekarang disucikan oleh agama.

Kesakralan keluarga mulai dipertanyakan, sebab dalam lindungan agama keluarga telah menjadi sebuah kodrat atau takdir. Padahal sebenamya keluarga hanya merupakan sebuah bentuk sosial bersama yang diakui atau diturunkan dari generasi ke generasi. Di mana relasi dilembagakan oleh para pengambil keputusan.

Inti keagamaan seperti iman dan taqwa pada dasamya adalah individual. Bagi seorang muslim tidaklah ia berdiri sendiri sebagai pribadi-pribadi yang terpisah dan membentuk masyarakat atau komunitas. Corak masyarakat didasarkan kepada kadar intensitas keagamaannya yang bersifat dari sangat agamis dan sampai yang kurang atau tidak agamis.

Berdasarkan pengertian di atas, maka pranata sebaga cara perilaku keislaman ialah pranata yang dapatdipandang sebagai perwujudan atau cerminan nilai-nilai keislaman, baik yang menyangkut material seperti masjid, madrasah, pesantren maupun immaterial yang menyangkuthubungan antara kyai dan santri, kegiatan pengajian dan lain-lain.

Bagi keluarga muslim, nilai-nilai Islammemang seharusnya (artinya secara normatif) menjadi bagian dari pranata keislaman yang sekaligus ikut menentukan sikap seseorang dalam mengantisipasi dan memecahkan setiap persoalan yang dihadapi.

Tetapi pada kenyataannya mereka dituntut untuk berdialog dan berinteraksi dengan kenyataan. Banyak s ekali faktor-faktor yang ikut membentuk kemandirian seorang anggota masyarakat selain faktor nilai-nilai keagamaan.

Bahkan tidakjarang terjadi tingkah lakuyang tampak bersifat keagamaan pun, setelah dianalisa lebih mendalam bermotifkan hal-hal yang mungkin justru bertentangan dengan $\mathrm{n}$ ilai-nilai keagamaan, $\mathrm{m}$ isalnya motif $\mathrm{k}$ edudukan, kekuasaan, kesukuan, kedaerahan dan banyak kepentingan.

Bisa terjadi antara nilai-nilai kultural yang termasuk di dalamnya nilainilai keagamaan dan tindakan yang dilakukan seseorang dalam hubungannya berfungsi sebagai pengontrol dan pengawasan terhadap tindakan, baik itu bersifat kelompok maupun pribadi. 
Sejumlah nilai agama bisa ditarik garis lurus dengan seperangkat tindakan tertentu betapapun tegasnya dipisahkan dan diidentifikasikan. Muslim yang mengetahui agamanya belum tentu mempraktekkannya dalam kehidupan keluarga bagi terwujudnya keluarga taat.

Konsep sosialisasi merupakan konsep yang menjelaskan tentang fungsi pendıdikan dalam keluarga. Dalam kamus sosiologi, sosialisasi diartikan sebagai proses mengkomunikasikan kebudayaan kepada warga masyarakat yang baru. Menurut Laslie istilah sosialisasi mencakup seluruh proses dalam mempelajari nilai-nilai, sikap-sikap, pengetahuan, berbagai ketrampilan dan norma budaya yang dimiliki masyarakat dalam arti mempelajari kebudayaan. Walaupun Laslie menekankan upaya mempelajari nilai-nilai, namun tidak berhenti di situ dan adanya transformasi yang menyangkut moral, kognitif dan afektif serta terjadi pelestarian kebudayaan termasuk di dalamnya nilai-nilai agama.

Dalam masyarakat tradisional sosialisasi hampir seluruhnya terjadi di dalam keluarga. Hal ini sangat memungkinkan karena segala bentuk aktivitas kehidupan sosial dari lingkungan keluarga dan alam sekitamya di mana merka bermukim dan bertempat tinggal (Budi Santoso, 1993: 8).

Ditinjau dari perspektif masyarakat sosialisasi adala hproses penyelarasan individu ke dalam suatu pandangan hidup (way of life) yang terorganisasi dan tradisi kebudayaan yang telah mapan.

Nampak dari proses itu, seorang individu belajar menyesuaikan dirinya pada'kelompok guna memperoleh tingkah laku sosial yang ada pada kelompok itu. Proses itu bermula, di mana seorang individu akan belajar tentang perilaku kelompoknya yang terdekat yaitu keluarga; orang tua dan anggota keluarga lainnya meliputi: disiplin diri, nilai-nilai yang dianut, norma-norma, peran yang harus dimiliki sesuai dengan statusnya dalam keluarga. Jika hal-hal tersebut sudah dimiliki oleh dirinya, maka dalam melakukan hubungan dengan luar keluarga d apat diperoleh s uasana pergaulan d engan temannya s ehingga memperoleh peran untuk menyesuaikan diri. Begitu pula akan menerima aturanaturan dan norma-norma yang berlaku pada kelompoknya. Ia akan aktif dan tidak hanya sebagai penonton yang pasif serta dapat memberikan sumbangan dalam kelompoknya. Terjadinya interaksi dengan orang lain yang dapat dan ikut membentuk kepribadiannya.

Mempelajari proses sosialisasi yang dialami oleh individu dalam suatu masyarakat kita akan dapat mengetahui lebih banyak tentang kebudayaan masyarakat itu. Oleh karena itu, pengkajian terhadap proses sosialisasi telah sejak lama mendapat perhatian para ilmuwan. 
H. Gerrts (1983) dengan penelitiannya di Mojorejo telah memberikan gambaran yang jelas tentang fungsi kekerabatan Jawa dalam kehidupan seharihari dan juga mengenal pembentukan dan perkembangan sikap mental dan orientasi nilai-nilai budaya orang Jawa umumnya dalam proses sosialisasinya melalui penanaman nilai dan norma yang dijabarkan dari sistem kepercayaankepercayaan yang disebut agama.

Husni Rahim (1982) dalam penelitiannya menekankan pada pewarisan nilai-nilai agama pada masyarakat Bugis di desa Bdjoe, Bone. Sedangkan pada penelitian ini memfokuskan pada penanaman nilai-nilai agama pada anak dan keluarga.

Berdasarkan uraian tersebut masalah yang muncul adalah makna-makna apa yang dapat disingkap dari upaya keluarga dalam membentuk, memiliki dan untuk mengembangkan perilaku yang berdasarkan nilai agama.

Makna yang representatif adalah sebagai berikut:

1. Nilai-nilai manakah yang dominan dilakukan oleh keluarga dalam sosialisasi.

2. Bagaimana cara mensosialisasikan nilai-nilai agama dalam keluarga muslim.

Dengan demikian tujuan dari penelitian ini ingin menyingkap apresiasi keluarga terhadap nilai agama dalam perilaku berdasarkan upaya keluarga dengan tingkat apresiasi secara kata hati (ikhlas), secara logika (nalar) serta secara naluri.

Maksud penelitian adalah mengamati sosialisasi nilai-nilai agama yang dapat membentuk kepribadiannya, di mana dinilai-nilai agama mewamai interaksi dalam keluarga muslim antara anak dengan ayah dan ibu.

\section{A. Perangka Pemikiran dan Perspektif Teori}

Sosialisasi dalam masyarakat memerlukan adanya wadah, di mana keluarga merupakan salah satu lembaga yang dapat memanifestasikannya. Melalui keluarga tatanan dilakukan selama mengadakan hubungan satu dengan lainnya. Hubungan antara orang tua dengan anak didasarkan pada peran yang dapat mengakomodasikan dan menghubungkan kepentingan dalam keluarga.

Kebahagiaan keluarga mengandung makna bahwa apresiasi diri mereka tidak harus dimaknakan dalam kerangka hubungannya dengan Allah (manusia transendental), tetai juga bermakna dalam kerangka hubungan dengan sesama, keluarga dan diri sendiri (ekumeni-transendental). 
Sayekti dalam penelitiannyajuga, menemukan bahwa nilai agama sangat besár pengaruhnya terhadap keberhasilan keluarga. Sikap anak terhadap nilainilai agama (shalat, mengaji), merupakan r ealisasi kepemilikannya yang diapresiasi melalui sosialisasi.

Bagi anak sangat logis jika merealisasikan nilai-nilai agama, karena dalam keluarga mempertautkan diri terhadap tujuan yang diinginkan oleh orang tuanya. Orang tua selalu menghindarkan diri dari perilaku kontradiktif dari tauladan, pewarisan dan tradisi dalam keluarga. Sehingga sosialisasi niali agama pada anak baik secara kata hati, nalar dan naluri terbina dengan baik.

Keluarga dengan identitas muslim merupakan bagian dari suatu unit sosial yang penting untuk diperhatikan secara fitrah, dan naluri berkeluarga adalah bagian yang terpenting dalam kehidupan manusia (surat ar-Rum: 21). Itulah sebabnya Islam memandang bahwa eksistensi keluarga merupakan sesuatu yang sakral dan sangat dihormati. Sehingga Allah SWT sangat membanci perceraian, putusnya ikatan kekeluargaan yang akan membawa implikasi kepada munculnya berbagai perilaku destruktif y ang dapat mengganggu dan mempengaruhi kehidupan ekonomi, sosial dan budaya kemasyarakatan.

Keluarga muslim mempunyai dua tanggung jawab dalam kehidupannya, yaitú tanggung jawab vertikal dan tanggung jawab horizontal. Tanggung jawab vertikal diwujudkan melalui komunikasi dan dialog dengan Tuhan, sedangkan tanggung jawab horizontal dilakukan melaluikomunikasi antar manusia. Dengan kata lain, keluarga muslim memiliki tanggung jawab yang dirinci dalam tiga hal berikut:

a. Tanggung jawab kepada Alllah SWT. karena keluarga dan fungsifungsinya merupakan pelaksanaan amanat dari Allah SWT.

h. Tanggung jawab kepada keluarga itu sendiri, terutama tanggung jawab orang tua sebagai pemimpin dalam keluarga.

c. Tanggung jawab keluarga sebagai u nit terkecil dan bagian dari masyarakat; menunjukkan penampilan yang positif bagi keluarga yang lain, masyarakat dan bangsa.

Dari tanggung jawab di atas maka peran-peran keluarga dalam kehidupan masyarakat sangatlah banyak. Ada dua peran utama dalam keluarga muslim pada lingkungan masyarakat yaitu sebagai pendidik dan penyebar amar ma'ruf nahi munkar (da'i/pendakwah).

Sebagai pendidik, keluarga menunjukkan kemampuan penting dalam satuán p endidikan kehidupan keluarga termasuk di dalamnya pembinaan 
hubungan dalam keluarga dan sosialisasi anak serta hubungan antara keluarga dengan masyarakat. Munculnya pendidikan kehidupan keluarga disebabkan oleh dua hal, yaitu:

a. Perkembangan kehidupan keluarga mempengaruhi perkembangan masyarakat.

b. Perubahan-perubahan yang terdapat di lingkungan akan mempengaruhi kehidupan keluarga.

Upaya orang tua dalam membentuk perilaku anak yang bercorak agama selain dari siklus k ehidupan s ecara I slami juga diperoleh dari m elatih, membiasakan dan mengembangkan nilai-nalai agama yang sesuai dengan dasar moral. Melatih, membiasakan dan mengembangkan dalam berperilaku terhadap nilai-nilai agama, orang tua dituntut untuk membantu agar anak dapat membaca perilakunya agar apakah anak tidak melakukan penyimpangan terhadap nilainilai agama atau tidak. Kesadaran ini akan menghindarkan anak dari mengulang kesalahan yang sama, serta dapat mengembangkan terhadap perilaku yang bersesuaian dengan nilai-nilai agama.

Dalam extemalisasi nilai yang dijumpai anak dalam pergaualan, kesadaran tersebut harus ditumbuhkan dan anak akan mampu membedakan mana yang sesuai dengan mana yang tidak sesuai dengan nilai-nilai agama (keimanan, ibadah dan akhlak).

Anak di dalam akan bertindak, didasarkan kepada kesadaran a kan rujukan nilai-nilai Islam dan anakmemiliki pengawasan diri sendiri secara internal berarti orang tua telah melakukan pengawasan dan bimbingan terhadap anak untuk berperilaku sesuai dengan nilai-nilai agama yang sekaligus kontrol orang tua terhadap pergaulan anak dengan teman sebayanya.

Orang tua melakukan komunikasi dengan anak agar anak tidak berperilaku agresif dan taat kepada nilai-nilai agama Islam. Anak selalu dibina untuk mampu mengobservasi dirinya sendiri. Tentunya anak dalam merespon nilai-nilai agama, lingkungan fisik dalam keluarga tertata secara dinamis, misalnya di rumah ada mushalla, hiasan dinding, lemari dan rak buku yang berisi dan bemuansakan agama. Penataan lingkungan fisik di atas dapat mempengaruhi anak dalam memiliki nilai-nilai agama. Akrabnya orang tua dengan anak dan menampakkan dekat dan intimnya mereka karena pola hubungan hormatnya anak kepada kedua o rang tua mengemas nilai-nilai agama tertata $\mathrm{k}$ arena lingkungan sosial anak memberikan rasa bahagia dan aman, akrab dan dapat menimbulkan emosi anak dengan baik. Serta menghadirkan situasi kebersamaan dalam keluarga (hubungan baik antara orang tua anak). 
Berkenaan dengan kehidupan agama pada masa kanak-kanak sampai usia 9 tahun, agama masih sangat realistis. Pada masa itu orang tua berusaha untuk mempersonifikasikan nilai-nilai Islam pada diri anak sehingga menjadikan bagian dari kehidupannya. Jika tidak ada, maka anak merasakan satu kekurangan. Dengan demikian nilai-nilai agama merupakan kebutuhan dalam dirinya.

Konsep sosialisasi merupakan konsep yang menjelaskan tentang fungsi pendidikan dalam keluarga. Dalamkamus sosiologi, sosialisasi diartikan sebagai "proses mengkomunikasikan kebudayaan kepada warga masyarakat yang baru". Untuk menjelaskan pengertian itu, Laslie menyatakan istilah sosialisasi mencakup seluruh proses dalam mempelajari nilai-nilai, sikap-sikap, pengetahuan berbagai ketrampilan dan norma budaya yang dimiliki masyarakat, dalam arti mempelajari kebudayaan.

Jika Laslie menekankan pada upaya mempelajari nilai-nilai dan norma budaya, maka Bernstein (dalam Mifflen, 1986: 267) memfokuskan pada proses transformasi yang menyangkut moral, kognitif, afektif kepada anak, lebih lanjut Bernistein mengemukakan:

"......Sosialisasi menunjukkan pada proses biologis yang ditransformasikan ke dalam suatu badan kebudayaan tertentu. Hal ini mengakibatkan bahwa proses sosialisasi merupakan proses kontrol yang kompleks, di mana kesadaran moral, kognitif dan afektif ditimbulkan pada anak dan diberikan suatu bentuk dan isi tertentu. Sosialisasi mempekakan anak terhadap berbagai tuntutan seperti hal-hal yang diwujudkan di dalam berbagai peran yang diharapkan akan dimainkannya".

Dengan demikian dapat disederhanakan bahwa sosialisasi itu mencakup penanaman nilai pendidikan yang ada dan berlaku pada suatu masyarakat tertentu dan pada kurun waktu tertentu, karena di dalam masyarakat selalu terjadi pergantian generasi sesuai dengan hukum siklus dalam dinamika kehidupan manusia, yakni lahir, dewasa, tua dan mati pasti dialami oleh setiap orang.

Sosialisasi yang paling awal terjadi di dalam keluarga, di mana anakanaksejak masa dilahirkan sampaimenjelang dewasa selalu berada di lingkungan keluarga, oleh karena itu keluarga merupakan lembaga yang sangat penting dalammenjaga kelangsungan kehidupan sosial budaya suatu masyarakat. Untuk itu Horton dan Hunt menegaskan bahwa keluarga sebagai faktor penentu utama 
bagi sosialisasi anak, karena keluarga merupakan kelompok primer yang pertama dari seorang anak dan di situlah awal perkembangan kepribadian.

Dalam masyarakat tradisional sosialisasi hampir seluruhnya terjadi di dalam keluarga atau kelompok. Hal ini sangat dimungkinkan karena segala bentuk aktivitas kehidupan sosial budaya berangkat dari lingkungan keluarga dan alam sekitarnya di mana mereka bermukim dan bertempat tinggal, seperti yang dikemukakan oleh Budhi S antoso bahwa, p roses pendidikan y ang berlangsung dalam setiap lingkungan sosial itu secara langsung berfungsi pula sebagai kegiatan pelestarian kebudayaan. Lebih lanjut dikatakan, pendidikan yang diselenggarakan sejak dini itu pada hakekatnya merupakan upaya untuk menanamkan dan mengukuhkan nilai-nilai budaya, norma-norma sosial dan pandangan hidup yang menjadi inti kebudayaan yang bersangkutan.

Sosialisasi merupakan suatu proses belajar yang biasa dimulai dalam lingkungan keluarga. Oleh karena dalam keluarga terdapat hubungan kerabat antara orang tua dengan anak dan anak dengan anak, maka akan terlihat proses psikologi sosial yang mendasari unsur sosialisasi seperti bentuk apa yang diajarkan, tingkat kepercayaan, rasa kedekatan, rasa percaya dan banyak lagi unsur-unsur psikologis yang mempengaruhi jalannya proses sosialisasi. Dalam masa-masa awal biasanya anak lebih dekat dengan ibunya yang bertindak sebagai pengasuh, karena dalam masyarakat tani sebagian besar aktivitas ini dipegang oleh wanita sebagai ibu dalam keluarga. Dalam masa perkembangan anak selanjutnya, maka peran itu diambil alih oleh bapak, atau kakak-kakaknya sebagai "guru" yang mengajarkan berbagai ilmu dan ketrampilan, baik secara langsung maupun tidak langsung.

Proses penanaman nilai pendidikan anak suatu aspek penting dalam mempertahankan pola hidup m asyarakat, sehingga setiap aktivitas a kan mengarah kepada pembentukan perilaku masyarakat yang kemudian menjadi kaidah-kaidah dalam masyarakat yang mewarnai hidup dalam kepercayaan, kesusilaan, kesopanan dan hukum.

Proses munculnya kaidah-kaidah yang ada dan berlaku pada suatu masyarakat dimulai dari pandangan terhadap nilai-nilai yang dianggap baik atau buruk yang berasal dari pengalaman manusia dalam berinteraksi dengan sesamanya. Selanjutnya nilai-nilai itu akan berpengaruh pada pola tertentu, yang apabila diabstraksikan menjadi kaidah-kaidah yang nantinya mengatur perilaku manusia dalam berinteraksi. Kaidah-kaidah tersebut bukan saja mengatur perilaku manusia, tetapi juga sebagai acuan dalam hidup bermasyarakat dan sekaligus merupakan pokok budaya manusia. Oleh karenanya nilai-nilai tersebut 
harus diwariskan kepada keturunan mereka, proses pewarisan ini dilakukan melalui sosialisasi. Sosialisasi nilai-nilai agama yang dilakukan melalui pendidikan setiap unit keluarga dalam Islam sangat bertanggungjawab terhadap masa depan kemanusiaan di dunia yakni mewariskan generasi yang kuat di kemudian hari.

\section{B. Metode Penelitian}

Penelitian ini adalah penelitian eksplorasi yaitu penelitian yang bertujuan memperdalam pengetahuan mengenai suatu gejala tertentu atau mendapatkan ide-ide baru mengenai gejala itu dengan maksuduntuk merumuskan masalahnya secara lebih rinci.

Menjelajahi dalam p enelitian ini merupakan sifat y ang ada u ntuk mengetahui suatu gejala, sehingga metode ini dapat lebih mengungkapkan data yang menyangkut gejala sosial dari suatu kelompok atau golongan tertentu.

Penelitian kasus ini sangat mendukung dapat proses pencarian data dalam mengungkap pembinaan keluarga muslim dan sosialisasi nilai-nilai agama pada anak, karena itu memerlukan pengamatan secara cermat dalam jangka waktu tertentu.

Dalam penelitian ini subyek penelitiannya adalah keluarga muslim, yaitu beruśaha memahami proses sosialisasi nilai-nilai agama dari ayah dan ibu terhadap anak, yangmendorong keluarga untuk tetap hidup dengan pola perilaku, tradiși dan norma secara Islam. Keluarga yang dimaksud adalah keluarga petani, keluarga muslim, yang taat, tekun beribadah aktif dalam kegiatan keagamaan dan terikat dalam sosial keagamaan.

Adapun yang dijadikan responden informan dalam penelitian ini adalah keluarga Sukiman (bapak, ibu dan putra-putrinya yang masih berada pada tingkat Sekolah Dasar Negeri). Bapak Sukiman sebagai PNS (Pengawas Sekolah), sedangkan ibu Sukiman sebagai PNS (kepala sekolah SD).

Pemilihan obyek penelitian ini didasarkan pada observasi awal yang menunjukkan bahwa keluarga yang dipakai sebagai responden menjädi cermin keberhasilan dalam penanaman nilai-nilai agama pada anak.

Adapun teknik pengumpulan data dilakukan melalui wawancara secara mendalam (indepth interview) dan observasi langsung di lokasi penelitian untuk memperkuat informasi yang diperoleh, maka data yang dikumpulkan dari pengalaman peneliti, dengan tujuan guna memperdalam pengertian peneliti tentang masyarakat yang diteliti atau penelitian diarahkan juga pada pengaruh 
lingkungan fisik dan sosial terhadap keberadaan keluarga dan nilai-nilai pendidikan.

Penelitian ini dianalisis secara deskriptif kualitatif, karena dianggap dapat mengamati perilaku yang ada pada keluarga muslim dalam mensosialisasikan nilai-nilai agama dan dapat memberikan interpretasi secara teoritik terhadap semua data yang telah dikumpulkan. Data kuantitatif dipergunakan sebagai penunjang data kualitatif yang menampakkan tujuan utama dalam penelitian ini.

Data yang diperoleh dianalisis, diklasifikasikan dan diinterpretasikan, sehingga dicapai titik temu dalam menjawab semua permasalahan dalam penelitian.

Nilai-nilai agama yang dijadikan dasar berperilaku dan yang diupayakan orang tua dalam bentuk sosialisasi tentunya terakomodasi secara tidak sama. Begitu cara di dalam keluarga mempunyai beberapa variabel karena masingmasing keluarga mempunyai kemampuan berbeda dalam menata kehidupan.

Dalammemahami keberadaan keluarga muslim pada nilai agama, peneliti terlebih dahulu mengajukan konsep yang berhubungan dengan masalah dan obyek penelitian.

Konsep yang terkandung dalamnilai agama seperti: nilai keimanan, ibadah dan akhlak. Dapat diasumsikan bahwa nilai tersebut terakomodasi dalam keluarga dengan adanya sosialisasi. Pada sosialisasi terhadap nilai agama dapat terproses secara pelatihan, bimbingan, membiasakan, suri tauladan dan nalar.

\section{Laporan Hasil Penelitian}

\section{Lingkungan Keluarga Sukiman}

Posisi rumah keluarga ini kurang lebih lima ratus meter dari masjid dan lingkungan pendidikan Islam.

Penataan lingkungan fisik yang dilakukan oleh bapak Sukiman, telah menyingkap adanya tujuan agar keluarga dan anak-anak memiliki nilai-nilai moral, nilai kebersihan, disiplin dan nilai agama.

Penampilan situasi dan k ondisi rumah y ang memberikan suasana betahnya anak berada dan berkumpul dengan bapak dan ibu menunjukkan penataan fisik rumah dirasakan oleh anak-anak sebagai "keberumahan" mereka pulang ke rumah tidak hanya sebagai tempat berteduh, tapi dirasakan tempat yang memberikan lindungan dan rasa aman yang berisi nilai moral dan agama. 
Nampak keberumahan pada keluarga ini tidak terlalu menunjukkan sifat Islámi seperti tidak banyak ditemukan tulisan secara Islam di rumah ini.

Bapak dan ibu Sukiman mempunyai tiga orang anak: Iskandar, Nur dan Tris, dirasakan kurangnya frekwensi perjumpaan anak-anak dengan bapak. Karena bapak Sukiman sering tidak ada di rumah.

Kebersamaan ini tidak dirasäan oleh bapak Sukiman. Ia sering pergi keluar untuk urusan masyarakat, ia dikenal sebagai pribadi yang taat beragama, cermin bagi kehidupan masyarakat, wibawa dalam masyarakat dan selalu diminta wawasan, saran-saran oleh masyarakat dalam lingkungannya.

Ibu Sukiman sebagai seorang guru di sekolah dasar, banyak dihabiskan waktunya oleh kegiatan sekolah.

Jadwal waktu bagi anak-anak untuk di rumah sudah ditetapkan, maka makna yang terkandung di dalamnya keterikatan a nak dan keterpaksaan terhadap sesuatu yang menjadi tanggung jawab anak.

Saat anak pulang sekolah, ibu dan bapak Sukiman tidak ada di dalamnya. Nampak situasi rumah menunjukkan kurang kondusif bagi mereka di dalam menerjunkan diri dan bergumul dengan nilai-nilai, terutama dengan nilai agama.

Mereka merasakan dan menganggap pulang ke rumah dalam keadaan lengang dan memberikan situasai dan kondisi dialog yang intensif antara mereka dengan orang tua.

Sering terjadi pertengkaran antara anak yang mengurangi suasana kebẹrumahan dikacaukan atau diganggu oleh tindakan anak, kadang-kadang kakak (Iskandar) menggoda adiknya sampai menangis. Oleh karena penting untuk disadari bahwa anak bagi bapak dan ibu keberumahan itu menentukan sosialisasi nilai pada anak dari orang tua.

Apabila bapak dan ibu sudah berada di rumah, keduanya menunjukkan sikap kepada anak-anaknya upaya secara optimal untuk dekat dan akrab dengan anak-anaknya. Bapak dan ibu Sukiman tidak segan-segan mengorbankan "kesenangannya" pada saat acara TV diputarkan dan menjadi kesenangannya jika anak-anak sedang belajar bapak Sukiman bersedia mengorbankannya. Begitu juga ibu, tatkala ada di rumah segala kesibukan yang tidak berorientasi kepada kepentingan kegiatan anak di rumah sebaiknya ditinggalkan. Belajamya anak di rumah, tidak hanya saat ada ulangan dan mengerjakan pekerjaan rumah, tapi setiap hari belajar.

Bapak Sukiman secara terus menerus menjaga keberadaan dirinya di rumàh pada saat maghrib. Shalat maghrib dan isya dilakukan dengan berjamaah 
di mana situasi ini dipergunakan olehnya untuk menampilkan sosok dirinya memberikan contoh dan pelajaran terhadap anak untuk berperilaku yang taat terhadap Allah SWT. dan santun terhadap orang yang lebih tua, yang akhirnya mereka merasakan sebagai undangan untuk belajar berperilaku secara agamis dan sopan terhadap orang lain.

Penataan rumah dan ruangannya ditampilkan dengan adanya ruang mushalla yang ditempatkan berhadapan dengan keluarga, kamar makan dan dekat dengan kamar mereka. Penataan ini bertujuan agar kontrol terhadap perilaku-perilaku anaknya dapat dilakukan secara fungsional. Tersedianya perangkat shalatuntuk masing-masing anggota keluarga, seperti al-Qur'an, bukubuku agama yang diperuntukkan dibaca anak-anak dan untuk dirinya, lafadz Allah dan Muhammad sebagai hiasan dinding di mushalla dan di ruang keluarga mencerminkan nafas keagamaan yang juga mempermudah terciptanya suasana kebersamaan yang ditampilkan dalam keselarasan perilaku.

Di dalamnya mencerminkan muatan-muatan nilai agama terlihat adanya alas kaki untuk di dalam rumah (sandal) yang khusus dipergunakan untuk melakukan shalat. Anak merasa terpanggil untuk belajar dan memiliki nilai agama dan dapat dibaca dari perilaku anak dalam menunaikan shalat jamaah. Mereka tetap melaksanakannya di rumah walaupun kedua orang tuanya tidak ada di rumah.

Nilai-nilai agama yang diperoleh dari keluarga diapresiasikan oleh anak dengan cara kata hati namun secara logika (nalar) banyak dilakukan di dalam keluarga ini.

\section{Sosialisasi Nilai-nilai Agama dalam Keluarga}

Frekwensi pertemuan orang tua dengan anak di dalam rumah (bapak dan ibu sering tidak di rumah) walaupun tidak dirasakan oleh anak sebagai tidak akrabnya mereka dengan orang tua, namun perilaku-perilaku mereka tidak menyimpang dari keinginan orang tua.

Kepedulian bapak dan ibu Sukiman terhadap perilaku anak dalam menyerap nilai-nilai agama dapat diamati dan dipahami dari dua faktor:

\section{a. Siklus Kehidupan Islam}

Warga masyarakat di desa Ambulu mengenal beberapa tahapan masa yang dilalui oleh seseorang dalam siklus keislaman. 
Mulai anak lahir sampai masa bayi anak didasarkan kepada terpeliharanya anak dari tingkah laku baik dan shaleh. Dengan pengalaman yang dilalui oleh anak akan nampak tingkah laku apa yang diharapkan orang tua.

Wujud nasehat, bimbingan, kasih sayang, landasan dari bapak dan ibu terhadap anak, selalu mengiringi pada tahapan kehidupan anak. Sampai anak dikhitan dan dianggap telah menjadi seorang Islam, di situlah harapan bapak dan ibu terhadap anak untuk menjadi shaleh dan shalehah.

\section{b. Sosialisasi Nilai-nilai Agama Anak pada Masa Sekolah}

Anak-anak pada keluarga bapak Sukiman memulai pada pendidikan di sekolah dasar (SD). Pendidikan agama di SD tidak sama dengan madrasah baik dari segi materinya ataupun dari segi pelaksanaannya.

Disadari oleh bapakdan ibu Sukiman untuk anak-anak, kurang mampunya anak di dalam pengetahuan keislaman. Iskandar, Nur dan Tri dikirim ke TPQ al-Hikam untuk memperbanyak pengatahuan keislaman dan membaca al-Qur'an (pendidikan non formal). Jenjang pendidikannya tidak berjenjang kronologis seperti pendidikan formal. Nantinya anak juga akan mengalami pendidikan infornal dalam masyarakat yang merupakan hasil pengalaman belajar individual.

\section{Pendidikan Formal}

Interpretasi terhadap lingkungan pendidikan di SD yang berbeda dengan madrasah dalam pemberian materi pendidikan agama Islam menyingkap makna nilai-nilai agama yang diapresiasikan anak dalam kehidupannya, bantuan yang diberikan orang tua terhadap anak dalam memahami dan menyadari serta memiliki akan pentingnya nilai-nilai agama bagi dirinya anak selalu diupayakan.

Bapak dan ibu Sukiman dalam penampilannya bersikap sebagai pendidik dalam keluarga.

Ditemukan oleh anak adanya apresiasi yang sama antara dirinya dengan orang tua. Oleh sebab itu terjadilah pertemuan makna antara anak dengan orang tua dalam nilai-nilai agama.

Anak sebagai terdidik dan orang tua sebagai pendidik terdapat pertemuan makna yang diapresiasikan bersama.

Yang d isuburkan dalam keluarga ini p enampilan perilaku d engan komunikasi dialogis, sehingga tampillah perilaku orang tua baikmelalui tauladan, dialog dan kepedulian yang sangat tinggi ditangkap oleh anak-anak sebagai 
dunia "orang tua yang utuh". Segala nilai yang diaktualisasikan oleh orang tua terutama nilai agama ditangkap oleh anak secara utuh dan benar.

Hal ini melahirkan kepercayaan dan wibawa orang tua terhadap anak dan anak banyak pasrah dan berserah pada orang tua.

Dialog-dialog mereka tentang nilaiagama yang diambil dari nilai pelajaran agama Islam di sekolah juga efektif dalam menyadarkan dan melatih anakanaknya untuk lebih mengamalkan nilai-nilai agama dalam kehidupan keseharian. Dialog-dialog dalam keluarga dirasakan oleh anak adanya kedekatan, keakraban, kebersamaan, dan keterpautan diri kepada keluarga termasuk di dalam nilainilai agama yang harus dijunjung tinggi.

Materi pelajaran agama Islam pada sekolah dasar diberikan secara umum. Akidah, ibadah dan akhlak diberikan secara terkait.

\section{Akidah}

Dalam keluarga Sukiman, anak-anak mengenal akan nilai agama dalam bidang akidah terfokus pada keimanan pada Allah SWT. Pengenalan anak pada keimanan secara utuh dalam rukun iman dicerna oleh anak dari sekolah sebagai konsep dan teori yang jarang disosialisasikan anak dalam kehidupan keluarga.

Bapak dan ibu Sukiman tidak menunjukkan perhatian khusus pada masalah ghaib, diterima oleh anak dari sekolah direspon oleh kedua orang tua sebagai sesuatu yang tidak sulit bagi orang tua untuk didialogkan dengan anak.

Jawaban yang benar dan tepat serta memuaskan dari orang tua terhadap masalah keimanan akan berdampak cukup besar terhadap kualitas keimanan anak. Menurut bapak dan ibu Sukiman, anaksering bertanya tentang nilai agama yang didapat dalam bidang akidah, misalnya tauhid kepada Allah SWT.

Anak-anak kurang mengerti bacaan-bacaan yang berorientasikan nilai akidah berupaya dan mendorong anak untuk memiliki, mengembangkan nilai ini. Kesiapan untuk memahami dan mengerti b agi a nak dalam hal ini, menumbuhkan aktivitas berfikir, rasa dan karsanya terus menerus dilandasi serta sekaligus menuju pada pentauhidan kepada Allah SWT.

Suasana keluarga yang sarat dengan kebersamaan, keakraban, kedekatan, pemberian teladan, sikap terbuka yang diciptakan oleh orang tua telah menyingkap adanya kondisi y ang dapat mengundang anak untuk mengetahui dan memiliki nilai-nilai agama dalam bidang akidah. 
Keorangtuaan bagi bapak dan ibu Sukiman betul-betul dirasakan anak sebagai pendidikan dan nilai agama yang berlaku bagi anak diapresiasikan pada tingkat nalar dan logika. Penampakan perilaku anak yang didasarkan pada apresiasi ini tercapai pada perilaku keseharian anak, bapak dan ibu Sukiman benar-benar konsisten dalam mendorong anak-anak memiliki nilai-nilai agama dalam bidang akidah.

\section{Ibadah}

Anak-anak menghayati dalam keberumahan, a da nilai kebersihan, kesucian dan keteraturan serta menempatkan peralatan shalat pada tempatnya masing-masing jika telah selesai melakukan shalat. Perbuatan tersebut tetap mereka lakukan setiap melakukan shalat. Di samping itu bapak dan ibu Sukiman menciptakan suasana kebersamaan untuk shalat berjamaah sebagai salah satu wujụd untuk mendekatkan dan mengakrabkan anak-anak dengan nilai-nilai agama dalam bidang ibadah.

Penghayatan anak-anak terhadap kedekatan dan keakraban dengan nilai agama dalam bidang ibadah tertampilkan dari realitas perilaku anak; shalat maghrib, isya' dan subuh yang dilakukan berjamaah (di rumah) serta shalat dhuliur di sekolah dan ashar di masjid (TPQ) bersama kawan-kawannya. Adanya kebersamaan anggota keluarga dalam shalat jamaah anak mengaji alQur'ân, bapakibu berupaya untukmenjaga kontinuitas ibadah dalam keluarga.

Pada keluarga ini lebih dimantapkan adanya posisi ibadah wajib seperti shalat lima waktu. Untuk ibadah yang lain seperti puasa, zakat dan haji, pada keluarga Sukiman tidak ditemukan realitasnya kecuali pada tingkat yang hukumnya wajib, misalnya mereka tidak melaksanakan puasa Senin dan Kamis.

Dalam segi ibadah, nampaknilai-nilai agama yang dilakukan pada keluarga ini, rạjin shalat, rajin mengaji al-Qur'an, menjaga kesucian mushalla.

Hal di atas memberikan konstribusi nilai dalam hubungan antara anggota yaitu sopan santun, hidup teratur, disiplin, kasih sayang dan nilai moral lainnya; karena hakekatnya nilai moral didasarkan pada nilai-nilai agama.

Menurut bapak dan ibu Sukiman, ibadah yang diapresiasikan oleh anak dalam keluarga sudah memadai bagi anak-anak yang dirasakan sebagai sesuatu penunaian kewajiban diri terhadap nilai-nilai agama; yang dimaknakan dalam kerangka hubungan dengan Allah SWT. dan hubungan dengan sesama manusiakeluarga dan dengan diri sendiri. Bentuk apresiasi seperti di atas berdasarkan 
kata hati. Terhadap ibadah yang lain, diapresiasikan oleh anak dalam tingkat nalar yang dibuktikan dengan adanya dialog.

\section{Akhlak}

Nampak pada keluarga Sukiman, tema "Baiti Jannati" yang ada dalam rumah; merupakan motto yang dianut oleh keluarga muslim.

Nilai agama yang diaktualisasikan sikap akhlak lebih bersifat pribadi. Dan kuatnya penanaman akhlak pada pribadi anak diupayakan oleh bapak dan ibu, walaupun dalam menggunakan bahasa sehari-hari tidak dengan bahasa baku. Antara a nak panggilan kepada masing-masing menyebut dengan singkatan nama seperti: Iskandar dengan sebutan (Is), Nur dan Tri.

Dalam berinteraksi di antara anak dan keluarga, bapak dan ibu dalam menanamkan nilai agama dari segi akhlak diciptakan suasana saling mencintai, menghormati, sifat mengabdi, setia dan taat serta melaksanakan nilai-nilai moral yang dijunjung tinggi oleh keluarga.

Dalam menanamkan akhlak kepada anak, selain memberi teladan yang tepat, menunjukkan kepada a nak t entang bagaimana i a harus bersikap menghormati dan berakhlakul karimah dalam kehidupan.

Jika orang tua bertindak yang tidak bersesuaian dengan sikap yang dihayati oleh anak, maka anak mengapresiasikan sikap itu dengan nalar (logika).

Menjadi dambaan bagi seorang anak agar dirinya memiliki nilai-nilai agama, sekaligus dapat menjadi seorang muslim yang berakhlak yang indah dan baik.

Sosialisași nilai-nilai agama pada anak dalam tatanan kehidupan bapak dan ibu Sukiman sebagai keluarga muslim adalah:

- Siklus kehidupan secara islami pada umumnya disosialisasikan dengan cara pewarisan sebagai wujud tanggung jawab orang tua.

- Pada masa pra sekolah, nilai agama disosialisasikan kepada anak (pengalaman agama) dengan pembiasaan, teladan dan bimbingan secara ikhlas dan kata hati.

- Pada masa sekolah, nilai-nilai agama disosialisasikan pada anak lebih banyak didialogkan oleh bapak dan ibu. Keimanan dan ibadah pada keluarga bapak Sukiman diapresiasikan oleh anak pada bidang-bidang yang dipelajari anak di sekolah dasar, yang tidak sama dengan di Madrasah Ibtidaiyah. 
Pada nilai agama dalam bidang akhlak, keluarga berupaya dengan benarbenar agar perilaku anak dapat memberi daya tahan tertentu terhadap keluarga.

Walaupun anak melihat figur bapak dan ibu sebagai pendidik, maka tokoh pendidik dipandang sebagai penuntun. Orang tua berusaha menghindarkan diri dari kontradiktif perilaku dan anak tetap menaruh kepercayaan kepada orang tua sebagai figur yang ideal, walaupun suatu saat anak masih mempertanyakan kebenarannya dalam berperilaku (berakhlak). Nilai-nilai agama dalam bidang akhläk masih akan menjadi konsumsi nalar/logis.

\section{Pendidikan Non Formal}

Penyelenggaraan pendidikan non formal yang dikenal satu-satunya adalah Taman Pendidikan Qur'an yang dikelola oleh yayasan al-Hikam. Anak-anak dari keluarga bapak Sukiman kesemuanya mengikuti pendidikan ini. Selain mengaji anak-anak sekaligus diberi pengetahuan dan nilai agama.

Menurut bapak dan ibu Sukiman; banyak diperoleh pengetahuan dan pengálaman dalam bidang agama sekaligus menambah wawasan anak memahami dan menghayati agama.

Sebelum anak mulai belajar, ia diharuskan berwudlu' terlebih dahulu, karen'a akan menghadapi kitab suci. Banyak perolehan dalam menghayati nilai keagamaan selama ada dalam mengikuti mengaji. Ada waktu-waktu tertentu bagi anak untuk kerjasama mengisi air untuk wudlu', membersihkan tempat mengaji dan halaman masjid.

Anak dalam lembaga non formal ini, dilatih hidup bermasyarakat yang lebih 'di samping manfaat untuk lebih merasakan pada dirinya bahwa ia adalah bagian dari kehidupan masyarakat. Anak akan mampu mempertautkan dunia keluarga dengan dunia masyarakat. Perhatian anak terhadap peristiwa-peristiwa yang terjadi dalam masyarakat nampak semakin besar.

Nilai-nilai yang dibangun oleh anak, ditegakkan atas dasar cinta, simpati, persahabatan, solidaritas dan keakraban dapat membuat anak merasakan kepemilikan dirinya terhadap nilai-nilai agama. 


\section{DAFTAR PUSTAKA}

'M.Y. Soelaiman: 1994. Pendidikan dalam Keluarga. Bandung. ALPABETA

${ }^{2}$ Soekanto, Surjono: 1977. Sosiologi Suatu Pengantar: Universitas Indonesia. Jakarta

${ }^{3}$ Mifflen, Frank: 1986. Terjemahan Joost Kullit. Sosiologi Pendidikan. Bandung, Tarsito

+ Budhi Santoso, S: 1993. Majalah Kebudayaan. Jakarta. Dept. P dan K Republik Indonesia

${ }^{5}$ Brown, M.A.W: 1986. Alam Manusia Dalam Fenomenologi. Jakarta. Gramedia

${ }^{6}$ Geertz, Hildrad: 1983. Keluarga Jawa, Penerjemah Hersri. Jakarta. Grafiti Press

'Sayekti Pujosuwarno: 1991. Makna Interaksi Antara Anggota Keluarga Dipandang Dari Sudut Konseling Keluarga. Bandung. IKIP.Bandung

${ }^{8}$ Susanto, Astrid, S: 1985. Pengantar Sosiologi Dan Perubahan Sosial. Bandung. Bina Citra

${ }^{9}$ Mitchell, Duncan: 1984. Sosiologi Suatu Analisa Sistem Sosial. Jakarta. Bina Aksara

${ }^{10}$ Horton, L. Hunt: 1987. Terjemahan. Sosiologi. Jilid I. Jakarta. Erlangga

$"$ "Budhisantoso, S: 1993. Majalah Kebudayaan. Jakarta. Dept. P dan K Republik Indonesia

12 Soekanto, Soerjono: 1993. Kamus Sosiologi. Jakarta. Rajawali Pers

*) Penulis adalah Dosen tetap Fakultas Psikologi 